\title{
ÍNDICE DE CAPACIDADE PARA O TRABALHO E DESEQUILÍBRIO ESFORÇO-RECOMPENSA RELACIONADO AO DISTÚRBIO DE VOZ EM PROFESSORAS DA REDE ESTADUAL DE ALAGOAS
}

\section{Index of workability and Effort-Reward imbalance related to voice disorder in Teachers in the state of Alagoas}

\author{
Cristiane Cunha Soderini Ferracciu (1), Daniela Monique Tavares dos Santos (1), \\ Phillipe Xavier de Barros (1), Liliane Reis Teixeira (2), Marcia Soalheiro de Almeida ${ }^{(2)}$
}

\begin{abstract}
RESUMO
Objetivo: verificar a associação entre distúrbio de voz e dados sociodemográficos e organizacionais (situações de violência) do trabalho docente, e entre perda de capacidade para o trabalho e estresse psicossocial no trabalho. Métodos: os participantes [faltou a coleta de voz para definir os grupos com e sem distúrbio de voz] foram solicitados a responder aos questionários Condição de Produção Vocal do Professor, Desequilíbrio Esforço-Recompensa e Índice de Capacidade para o Trabalho. Resultado: foi encontrada associação entre distúrbio de voz e os dados sociodemográficos e organizacionais do trabalho no que diz respeito ao tempo que leciona $(p=0,028)$, ao número de escolas em que leciona $(p=0,004)$ e às situações de violência no quesito depredação $(p=0,037)$. Não houve significância entre o distúrbio de voz e os escores dos questionários Desequilíbrio EsforçoRecompensa e Índice de Capacidade para o Trabalho ( $p>0,05)$. Houve associação entre os dados sociodemográficos e os questionários Desequilíbrio Esforço-Recompensa e Índice de Capacidade para o Trabalho, relacionada à faixa etária $(p=0,042)$ e à variável "Trabalha em outro local diferente da escola" ( $p=0,011)$, respectivamente. Conclusão: observa-se que professoras que possuem mais de 11 anos de docência, lecionam em duas ou mais escolas e trabalham em escolas que sempre têm depredações e violência contra os funcionários apresentam maiores chances de ter distúrbio de voz. Não houve associação entre a perda da capacidade para o trabalho e a presença do distúrbio de voz. O estresse psicossocial não mostrou significância com a presença do distúrbio de voz, mas apresentou associação com a faixa etária, observando-se Alto Desequilíbrio Esforço-Recompensa nas professoras mais jovens.
\end{abstract}

DESCRITORES: Qualidade de Vida; Voz; Docentes; Saúde Ocupacional

(1) Universidade Estadual de Ciências da Saúde de AlagoasUNCISAL, Maceió, AL, Brasil.

(2) Centro de Estudos da Saúde do Trabalhador e Ecologia Humana (CESTEH / ENSP / Fiocruz), Rio de Janeiro, RJ, Brasil.

Source of aid for research: Research Foundation of the State of Alagoas- FAPEAL

Work conducted in the Phonoaudiology Course, State University of Health Sciences of Alagoas - UNCISAL - Maceió (AL), Brazil.

Conflict of interest: non-existent

\section{INTRODUCTION}

Among the professionals who use their voices as main work tool, the teacher is the subject of most research in speech therapy. The Brazilian literature has a large number of studies aimed at the characterization of voice problems in teachers ${ }^{1}$ and cites a high prevalence of voice disorders, using the same instrument, and $63,1 \%$ for Brazilian teachers ${ }^{2}$, and $57,7 \%$ for Americans ${ }^{3}$. 
The precarious conditions of teaching are shown associated with morbid symptoms and are related to environmental conditions, work organization, health and quality of life as well as the ways in which the teacher lives, realizes and expresses these conditions and their daily confrontations ${ }^{4}$.

These conditions are directly related to risk factors for dysphonia, because they generate vocal abuse and can also contribute to the emergence of emotional and mental problems ${ }^{5,6}$. It is common to observe discipline in classrooms and a large number of students in this way, efficient communication between teachers and students are impaired, generating a greater physical and mental effort on the part of teachers.

Thus, voice changes have presented significant limitations in the development of teaching, bringing serious consequences, such as: loss of working days $^{7}$; emotional and psychological ${ }^{8}$ problems that lead to reduced well-being and quality of life, and, finally, social isolation ${ }^{9}$. In addition, these changes generate situations of removal and temporary incapacity for the performance of the teaching function, causing losses social, economic and professional ${ }^{10}$.

Although there is a commitment to recognize the teacher's voice disorder, the list of notifiable diseases of the Unified Health System (SUS). Unfortunately, there is still no standard legal definition of conduct, not only by the absence of specific legislation on health and safety at work, but also by the absence of criteria for reporting in SUS, which prevents the identification of the real dimension of the offense, the planning and the adoption of relevant policy measures to the Ministries of Health (MS); Labor and Employment (MTE); Social Security (MPS) and society in general about their causes and determinants ${ }^{11}$.

The World Health Organization states that quality of life with regard to the way the individual lives, according to the context in which it is inserted, involving the socio-cultural, physical and psychological factors ${ }^{12}$. Epidemiological studies show that the prevalence of voice disorders is significantly higher in teachers when compared to non-teachers as well as the persistence of these disorders throughout their lives ${ }^{4}$.

The term "capacity for work" (ICT) refers to a condition resulting from the combination of human resources, physical, mental and social demands of work, organizational aspects and work environment, and is expressed as the well level being in which a worker is presently or in the near future as well as how he is able to perform their work to the demands of their health and their physical and mental abilities $^{13}$.
In Brazil two studies stand out for using ICT in teaching. Marquese and Moreno (2009) ${ }^{14}$ applied ICT in 154 university professors. The results revealed that the majority $(87 \%)$ of the teaching presented good or excellent workability; that satisfaction in the exercise of teaching can enhance the ability to work professional in this area and that teachers are satisfied with the activity performed, as well as the environment in which they live.

Giannini $(2010)^{15}$ conducted a case-control study with 167 teachers with change in ENT and voice perceptual ratings and 105 teachers without changes in these two assessments to determine the association between voice disorder, stress at work and loss of earning capacity. The author concluded that the lowest category and moderate capacity for work are associated with the presence of voice disorder.

A study of teachers of a municipal school network of São Paulo investigated the association between voice disorder and stress at work and loss of ability to work, using case-control, in which case group was formed by teachers with changes in ratings voice and larynx and the control group with no change in the ratings. The authors pointed out that there was an association between the voice disorder and stress at work, as well as between the speech disorder and the loss of capacity for work ${ }^{16}$.

The study on the imbalance between effort and reward - specifically the model of Effort-Reward Imbalance (DER) - and its relationship to health seeks to understand the contribution of social and psychological factors for the health and human disease ${ }^{17}$. "Effort" refers to the time pressure, breaks and physical overload that the worker must fulfill, namely the obligations perceived by the employee; and "reward" in turn, is made up of financial gain (adequate salary), self-esteem (respect and support from colleagues and superiors) and occupational status (promotion prospects, job security and social status $)^{17}$.

The teacher's voice is an important resource for oral communication and its disorders can have important repercussions for your personal and professional life. Thus, the objective of the study is to investigate the association between the voice disorder and demographic data, violent situations in teaching, the loss of ability to work ${ }^{18}$ and psychosocial stress at work ${ }^{17}$.

\section{METHODS}

This is an epidemiological study analytic cross sectional. This procedure was approved by the Ethics Committee of the National School of Public Health Sergio Arouca - ENSP, with Protocol 227/11 
and the State University of Health Sciences of Alagoas - UNCISAL, Protocol 1345/10.

This research involved 110 teachers of the female elementary school ( $1^{\text {st }}$ to $9^{\text {th }}$ grade) of Alagoas State Education Network - REEAL. It selected a representative sample of teachers from schools subordinated to 04 (four) Coordination Regional Education (CRE) in the city of Maceio. Search for selection of teachers, allocation proportional to the number of teachers was held in each CRE and drawn at random by the registration list provided by each CRE.

The perceptual analysis was performed with recording of the voices directly into a laptop (HP Pavilion Entertainment PC) with headset microphone of the brand Plantronics Audio 20 with $45^{\circ}$ pickup angle, positioned at a fixed distance of five centimeters the individual's mouth. The vocal sample consisted of speech tasks: sustained vowel $\mathrm{la/}$ and counting of numbers 1-10 in comfortable frequency and intensity. The parameter selected for analysis was the G, general degree of vocal deviation, recorded on visual analog scale (VAS) of 100 units.

The results of VAS were categorized according to the proposed by Yamasaki et al. (2008) ${ }^{19}$ : to 35,5 units as variability Normal Quality Vocal (VNQV), from 35,6 to 50,5 as mild to moderate, from 50,6 to 90,5 as moderate to intense level and above 90,5 as intense. The two extremes, 0, 100 and left, right, correspond respectively to the absence of voice deviation and maximum voice deviation. Thus, two groups emerged: vocal-disorder with CDV $(>35,5)$ and without SDV vocal-disorder (0 to 35,5 ).

In order to minimize the subjective aspects of the evaluation and control possible measurement bias, it was decided in this study use three speech therapists judges, experts in voice and time higher performance to five years in voice clinic who did not know the purpose of research and evaluating the voices in three different moments. It was decided to use the average of three times for being the average statistical measure most often used for numerical variables.

The subjects underwent questionnaire Professor Vocal Production Condition - CPV-P20, to raise demographic and organizational data of teaching; and the questionnaire Capacity Index for Work $I C T^{18}$, in order to assess the capacity for work considering physical and mental demands as well as the resources and the health condition of the workers according to their perception. Also responded to the questionnaire Effort-Reward Imbalance - DER ${ }^{17}$, in order to measure the level of stress to which the worker is exposed. The teachers also received an envelope containing a copy of the questionnaire and a copy of the Consent and Informed - IC.

The Capacity Index instrument for Work was developed and validated in English by the Finnish Institute of Occupational Health $(\mathrm{FIOH})$, translated and tested for Portuguese ${ }^{18}$. This instrument evaluates the capacity for work considering the physical and mental demands and resources and the health condition of the workers according to their perception. It allows early diagnosis of loss of capacity to work for prevention programs, maintenance and health promotion assist in occupational health and worker, regardless of the age factor, should be used to reduce the risk of disability in the future next WAl evaluates seven dimensions: capability for the current job compared with the best of all life; ability to work in relation to the demands of the job; number of diseases diagnosed by a physician; loss estimated work due to illness; absence from work for illness; own prognosis of ability to work and eventually mental resources. The generated score ranges 7-49 points, of which 7-27 correspond to low capacity for work, 28-36, the moderate ability, 37-43, good capacity and 44-49, the optimal capacity.

The imbalance between Scale Effort-Reward [now presents capitalized sometimes not - uniform] is used to measure the level of stress to which the worker is exposed. The final questionnaire contains 23 questions, arranged in three-dimensional scales: effort (six items); reward (11 items) - these divided into three subscales: estimates (five items), promotion prospects in employment and wages (four items) and safety (two items) - and, finally, overcommitment (six items). On the scales of effort and reward, responses vary in the degree of agreement or disagreement, with scores ranging from 1 to 5 . In the overcommitment scale, the answers range from strongly disagree and agree strongly with scores between 1 and $4^{17}$.

For the analysis of data from demographic and organizational data was performed a descriptive analysis using mean, median and standard deviation and analytical statistical analysis using the Chi-square test and Pearson exact fisher, through the SPSS (Statistical Package for social Sciences) in version 17 and STATA in version 1 was considered the dependent variable the presence of the voice disorder and the independent results of the questionnaires ability Index for the job (ICT) and Scale Effort-Reward Imbalance (DER).

\section{RESULTS}

The age of the surveyed teachers ranged from 29 to 62 years old, with an average of 45,8 years 
old. As for sociodemographic characteristics, we highlight the following: the range from 29 to 39 was the least prevalent of the three groups, with $22,7 \%$ of the sample, and the percentages of the other two groups ranged from $38,2 \%$ (40-49 years old) to $39,1 \%(50-62)$; the majority $(63,6 \%)$ were married or had stable, the rest were separated/widowed $(20,9 \%)$ or single $(15,5 \%)$. The vast majority $(95,5 \%)$ had complete higher education; slightly more than half $(50,9 \%)$ taught between 11 and 20 , and the rest was divided equally between who taught there up to 10 and even 21 or older $(24,5 \%)$. Just over half $(51,8 \%)$ taught in one school and the rest $(48,2 \%)$ in two or three schools; the most frequent weekly duration was 21-30 hours, with about half of the group $(49,1 \%)$ and the second highest percentage $(30,9 \%)$ corresponded to those that had a workload of 20 hours; only $9,1 \%$ worked in a different location of the school.

In socio-demographic results it was found, to the margin of error fixed (5,0\%), a significant association between the presence of voice disorder, the time it teaches and the number of schools that teaches. For such variables, the percentage with voice disorder was higher among teachers who teach between 11 and 20 years $(44,6 \%)$ and lower among those who teach there until 10 years $(14,8 \%)$; higher among those who teach in two or three schools than among those who teach in one school $(49,1 \%$ vs. $22,8 \%$ ). The teachers who teach for more than 10 years have 2,5 to 3,0 more likely to have the voice disorder when compared to the group who teaches there 10 years. The teachers who teach in more than one school are 2,15 more likely to have the voice disorder when compared to the group who teaches at only one school.

Significant associations were found between the presence of voice disorder and violent situations at school that refer to organizational data of teaching (Table 1).

Local de inserção da tabela 1 (autores: não inserir as tabelas aqui, é apenas uma marcação)

DER scale the results were used in four categories (Low effort and high reward, high stress and high reward: Low effort and low reward, high effort and low reward) and two categories (Low/Medium, High), and ICT into categories (low, moderate and good) in the whole group. Thus, it appears that most teachers $(62,7 \%)$ were classified with low stress and low reward and the percentage of the other three categories ranged from $9,1 \%$ to $15,5 \%$. In DER scale study of two categories, the majority $(64,5 \%)$ were classified in the "Low/medium" and the remaining $35,5 \%$ in the "High" category. With regard to ICT, most of the teachers were classified as low to moderate ICT, totaling $99,1 \%$. No teacher had great ICT.

In Figure 1 are the mean and the standard deviation of the ICT scores according to the occurrence of voice disorder.

Local de inserção da figura 1

Table 2 presents the association's study scores of scales imbalance Effort-Reward (DER) and Capacity for Work Index (ICT) with the groups with vocal disorder (CDV) and without vocal disorder (SDV). Figure 2 shows the prevalence of voice disorder according to four categories of DER.

Local de inserção da tabela 2 e figura 2

This study also allowed realizing the association of socio-demographic data with the DER and ICT scales. DER in scale, it turns out that "age group" was the only variable with significant association and for this variable is observed that the percentage of those who had high DER decreased with increasing age, being $56,0 \%$ in the range up to $39,32,6 \%$ in the range $40-49$ years and $26,2 \%$ in the group aged 50 or more. The teachers who were younger than 40 have 1,53 to 1,68 higher prevalence ratios (PR) compared to the group less than 40 years old. In relation to ICT, the variable "It works in a different school site" was the only variable significantly associated with the results of ICT, and this variable is found that the percentage with low ICT was higher in working than among those did not work at another location other than the school $(60,0 \%$ vs. $20,0 \%$ ). The teachers working in a different school site have 3,0 more likely to have the voice disorder when compared to the group that does not work elsewhere.

\section{DISCUSSION}

This study was conducted with teachers who, in their majority, were aged between 40 and 49, as similar to what was observed in another study 19 which found that most of the individuals belonged to the age group 30-49 years information those that are in line with other studies in the literature ${ }^{5,21-23}$. Other features found in most of the group, as a profession of time between 11 and 15 years, working hours 31-40 hours per week and work predominantly in a single school are also similar to data from other surveys of the same category of professionals ${ }^{22,24}$.

It is known that the more years of exposure to teaching, more likely to have voice disorder, although the literature is controversial regarding the association of the profession time and voice disorder ${ }^{23,25}$. The high weekly working hours in the teaching activities, family responsibilities, 
Table 1 - The group of teachers with voice disorder and without voice disorder, according to the situations of violence that occurred in the school environment.

\begin{tabular}{|c|c|c|c|c|c|c|c|c|}
\hline \multirow{3}{*}{ Variable } & \multicolumn{4}{|c|}{ Voice disorders } & \multirow{2}{*}{\multicolumn{2}{|c|}{ Total Group }} & \multirow{3}{*}{$P$ value } & \multirow{3}{*}{ RP (IC to $95 \%)$} \\
\hline & \multicolumn{2}{|c|}{ CDV } & \multicolumn{2}{|c|}{ SDV } & & & & \\
\hline & $\mathrm{n}$ & $\%$ & $\mathrm{n}$ & $\%$ & $\mathrm{n}$ & $\%$ & & \\
\hline TOTAL & 39 & 35,5 & 71 & 64,5 & 110 & 100,0 & & \\
\hline \multicolumn{9}{|c|}{ - Depredations } \\
\hline Never & 6 & 18,8 & 26 & 81,3 & 32 & 100,0 & \multirow[t]{3}{*}{$p^{(1)}=0,037^{*}$} & 1,00 \\
\hline Sometimes & 16 & 37,2 & 27 & 62,8 & 43 & 100,0 & & $1,98(0,87$ a 4,50$)$ \\
\hline Always & 17 & 48,6 & 18 & 51,4 & 35 & 100,0 & & $2,59(1,17$ a 5,75$)$ \\
\hline \multicolumn{9}{|c|}{ - Personal objects stolen } \\
\hline Never & 9 & 28,1 & 23 & 71,9 & 32 & 100,0 & \multirow[t]{3}{*}{$\mathrm{p}^{(1)}=0,223$} & 1,00 \\
\hline Sometimes & 16 & 32,7 & 33 & 67,3 & 49 & 100,0 & & $1,16(0,59$ a 2,30$)$ \\
\hline Always & 14 & 48,3 & 15 & 51,7 & 29 & 100,0 & & $1,72(0,88$ a 3,35$)$ \\
\hline \multicolumn{9}{|c|}{ - Objects from school stolen } \\
\hline Never & 12 & 30,8 & 27 & 69,2 & 39 & 100,0 & \multirow[t]{3}{*}{$\mathrm{p}^{(1)}=0,554$} & 1,00 \\
\hline Sometimes & 16 & 34,8 & 30 & 65,2 & 46 & 100,0 & & $1,13(0,61$ a 2,09$)$ \\
\hline Always & 11 & 44,0 & 14 & 56,0 & 25 & 100,0 & & $1,43(0,75$ a 2,73$)$ \\
\hline - Threat to te & & & & & & & & \\
\hline Never & 11 & 26,8 & 30 & 73,2 & 41 & 100,0 & $\mathrm{p}^{(1)}=0,332$ & 1,00 \\
\hline Sometimes & 20 & 41,7 & 28 & 58,3 & 48 & 100,0 & & $1,55(0,85$ a 2,85$)$ \\
\hline Always & 8 & 38,1 & 13 & 61,9 & 21 & 100,0 & & $1,42(0,68$ a 2,99$)$ \\
\hline - Police inter & & & & & & & & \\
\hline Never & 10 & 29,4 & 24 & 70,6 & 34 & 100,0 & $\mathrm{p}^{(1)}=0,145$ & 1,00 \\
\hline Sometimes & 12 & 29,3 & 29 & 70,7 & 41 & 100,0 & & $1,00(0,49$ a 2,01$)$ \\
\hline Always & 17 & 48,6 & 18 & 51,4 & 35 & 100,0 & & $1,65(0,89$ a 3,08$)$ \\
\hline - Racism & & & & & & & & \\
\hline Never & 25 & 36,8 & 43 & 63,2 & 68 & 100,0 & $\mathrm{p}^{(1)}=0,400$ & $1,65(0,66$ a 4,15$)$ \\
\hline Sometimes & 10 & 41,7 & 14 & 58,3 & 24 & 100,0 & & $1,88(0,70$ a 5,02$)$ \\
\hline Always & 4 & 22,2 & 14 & 77,8 & 18 & 100,0 & & 1,00 \\
\hline - Indiscipline & & & & & & & & \\
\hline Never & 1 & 14,3 & 6 & 85,7 & 7 & 100,0 & $\mathrm{p}^{(2)}=0,508$ & 1,00 \\
\hline Sometimes & 14 & 34,1 & 27 & 65,9 & 41 & 100,0 & & $2,39(0,37$ a 15,41$)$ \\
\hline Always & 24 & 38,7 & 38 & 61,3 & 62 & 100,0 & & $2,71(0,43$ a 17,09$)$ \\
\hline - Fights & & & & & & & & \\
\hline Never & 6 & 31,6 & 13 & 68,4 & 19 & 100,0 & $\mathrm{p}^{(1)}=0,591$ & 1,00 \\
\hline Sometimes & 12 & 30,8 & 27 & 69,2 & 39 & 100,0 & & $0,97(0,43$ a 2,20$)$ \\
\hline Always & 21 & 40,4 & 31 & 59,6 & 52 & 100,0 & & $1,28(0,61$ a 2,68$)$ \\
\hline - Agressions & & & & & & & & \\
\hline Never & 10 & 35,7 & 18 & 64,3 & 28 & 100,0 & $p^{(1)}=0,612$ & 1,00 \\
\hline Sometimes & 12 & 30,0 & 28 & 70,0 & 40 & 100,0 & & $0,84(0,42$ a 1,67$)$ \\
\hline Always & 17 & 40,5 & 25 & 59,5 & 42 & 100,0 & & $1,13(0,61$ a 2,10$)$ \\
\hline - Shots & & & & & & & & \\
\hline Never & 35 & 35,4 & 64 & 64,6 & 99 & 100,0 & $p^{(2)}=0,144$ & 1,00 \\
\hline Sometimes & 1 & 14,3 & 6 & 85,7 & 7 & 100,0 & & $0,40(0,06$ a 2,53$)$ \\
\hline Always & 3 & 75,0 & 1 & 25,0 & 4 & 100,0 & & $2,12(1,13$ a 3,97$)$ \\
\hline - Insults & & & & & & & & \\
\hline Never & 8 & 26,7 & 22 & 73,3 & 30 & 100,0 & $\mathrm{p}^{(1)}=0,368$ & 1,00 \\
\hline Sometimes & 15 & 34,9 & 28 & 65,1 & 43 & 100,0 & & $1,31(0,64$ a 2,69$)$ \\
\hline Always & 16 & 43,2 & 21 & 56,8 & 37 & 100,0 & & $1,62(0,81$ a 3,26$)$ \\
\hline - Violence ou & & & & & & & & \\
\hline Never & 10 & 23,8 & 32 & 76,2 & 42 & 100,0 & $\mathrm{p}^{(1)}=0,057$ & 1,00 \\
\hline Sometimes & 20 & 48,8 & 21 & 51,2 & 41 & 100,0 & & $2,05(1,10$ a 3,83$)$ \\
\hline Always & 9 & 33,3 & 18 & 66,7 & 27 & 100,0 & & $1,40(0,65$ a 2,99$)$ \\
\hline - Violence ag & & & & & & & & \\
\hline Never & 17 & 24,6 & 52 & 75,4 & 69 & 100,0 & $p^{(1)}=0,008^{*}$ & 1,00 \\
\hline Sometimes & 15 & 55,6 & 12 & 44,4 & 27 & 100,0 & & $2,25(1,32$ a 3,84$)$ \\
\hline Always & 7 & 50,0 & 7 & 50,0 & 14 & 100,0 & & $2,03(1,04$ a 3,95$)$ \\
\hline - Problems w & & & & & & & & \\
\hline Never & 10 & 28,6 & 25 & 71,4 & 35 & 100,0 & $p^{(1)}=0,569$ & 1,00 \\
\hline Sometimes & 13 & 37,1 & 22 & 62,9 & 35 & 100,0 & & $1,30(0,66$ a 2,56$)$ \\
\hline Always & 16 & 40,0 & 24 & 60,0 & 40 & 100,0 & & $1,40(0,73$ a 2,67$)$ \\
\hline - Graffiti & & & & & & & & \\
\hline Never & 13 & 31,7 & 28 & 68,3 & 41 & 100,0 & $p^{(1)}=0,348$ & 1,00 \\
\hline Sometimes & 8 & 28,6 & 20 & 71,4 & 28 & 100,0 & & $0,90(0,43$ a 1,89$)$ \\
\hline Always & 18 & 43,9 & 23 & 56,1 & 41 & 100,0 & & $1,38(0,79$ a 2,44$)$ \\
\hline
\end{tabular}

Legend: $\left(^{*}\right)$ : Significant association to level $5,0 \%$. $\left({ }^{* *}\right)$ : It has not been possible to determine due to the occurrence of very low frequencies. (1): Pearson's Chi-square Test. (2): Fisher's exact test. CDV: With vocal disorder

SDV: Without vocal disorder. RP: Ratio of prevalence. IC: Confidence interval 


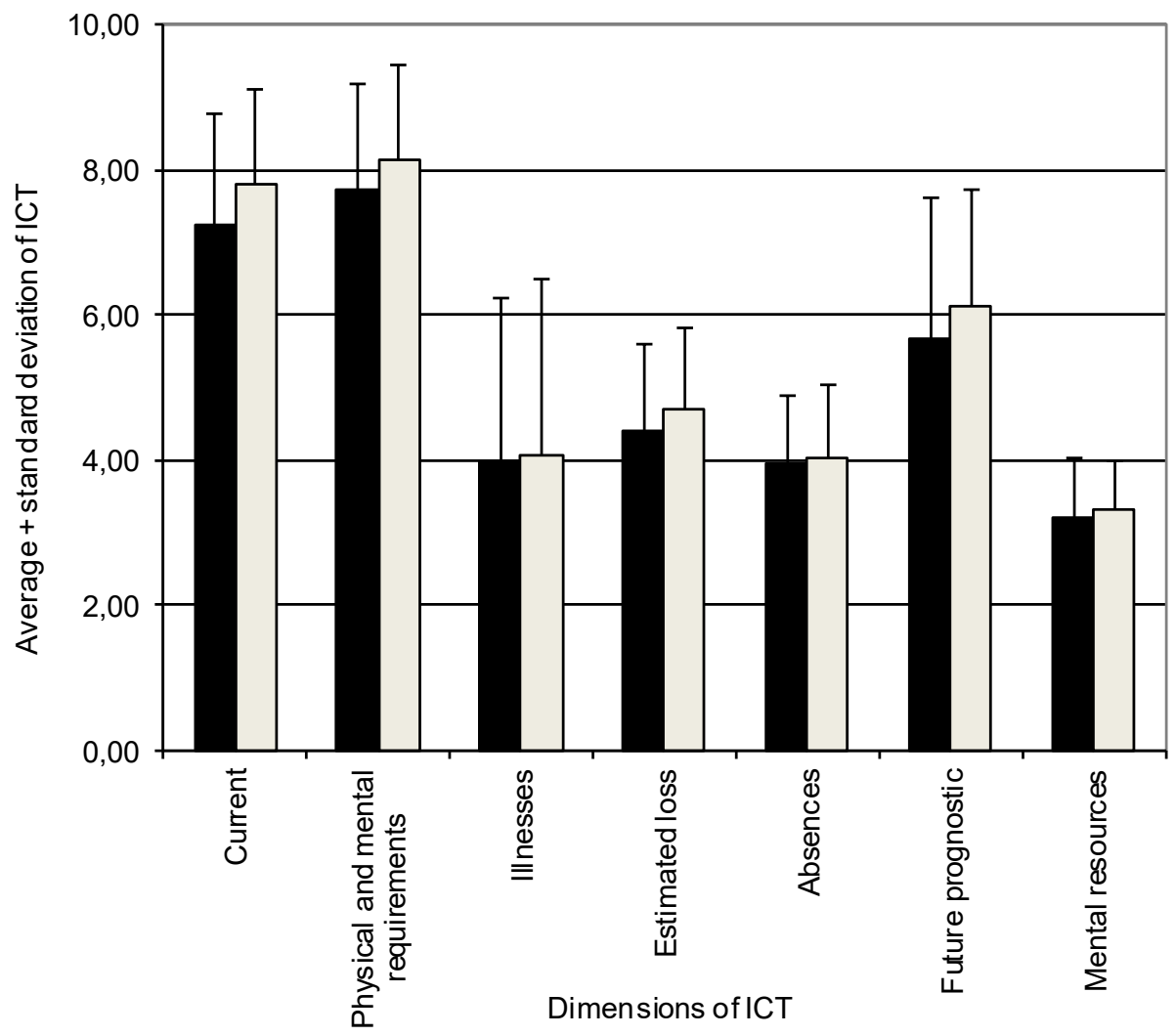

With voice disorder

$\square$ Without voice disorder

Legend: ICT- Index of Ability to Work

Figure 1 - Average and Standard Deviation of the scores of the Index of Ability to Work according to the occurrence of voice disorder.

Table 2 - Analysis of the scores of the Effort-Reward Imbalance Scales (DER) and Index of Ability to Work (ICT) with the CDV group and SDV.

\begin{tabular}{|c|c|c|c|c|c|c|c|c|}
\hline \multirow{3}{*}{ Variable } & \multicolumn{4}{|c|}{ Voice disorders } & \multirow{2}{*}{\multicolumn{2}{|c|}{ Total Group }} & \multirow{3}{*}{$P$ value } & \multirow{3}{*}{ RP (IC to $95 \%)$} \\
\hline & \multicolumn{2}{|c|}{ CDV } & \multicolumn{2}{|c|}{ SDV } & & & & \\
\hline & $\mathrm{n}$ & $\%$ & $\mathrm{~N}$ & $\%$ & $\mathrm{n}$ & $\%$ & & \\
\hline TOTAL & 39 & 35,5 & 71 & 64,5 & 110 & 100,0 & & \\
\hline \multicolumn{9}{|l|}{ - DER with 4 categories } \\
\hline Low effort + High reward & 2 & 20,0 & 8 & 80,0 & 10 & 100,0 & $\mathrm{p}^{(1)}=0,463$ & ** \\
\hline High effort + High reward & 7 & 41,2 & 10 & 58,8 & 17 & 100,0 & & $* *$ \\
\hline Low effort + Low reward & 23 & 33,3 & 46 & 66,7 & 69 & 100,0 & & ** \\
\hline High effort + Low reward & 7 & 50,0 & 7 & 50,0 & 14 & 100,0 & & ** \\
\hline \multicolumn{9}{|l|}{ - DER with 2 categories } \\
\hline Low/ Middle & 25 & 35,2 & 46 & 64,8 & 71 & 100,0 & $\mathrm{p}^{(2)}=0,943$ & 1,00 \\
\hline High & 14 & 35,9 & 25 & 64,1 & 39 & 100,0 & & $1,02(0,60$ a 1,72$)$ \\
\hline \multicolumn{9}{|l|}{$\bullet \mathrm{ICT}$} \\
\hline Low & 13 & 50,0 & 13 & 50,0 & 26 & 100,0 & $\mathrm{p}^{(1)}=0,151$ & ** \\
\hline Moderate & 26 & 31,3 & 57 & 68,7 & 83 & 100,0 & & $* *$ \\
\hline Good & - & - & 1 & 100,0 & 1 & 100,0 & & $* *$ \\
\hline
\end{tabular}

Legend: $\left({ }^{* *}\right)$ : It has not been possible to determine due to the occurrence of zero and very low frequencies. (1): Fisher's exact test. (2): Pearson's Chi-square Test. CDV: With Vocal Disorder. SDV: Without Vocal Disorder. RP: Ratio of Prevalence. IC: Confidence Interval. DER: Effort-Reward Imbalance. ICT: Index of Ability to Work. 


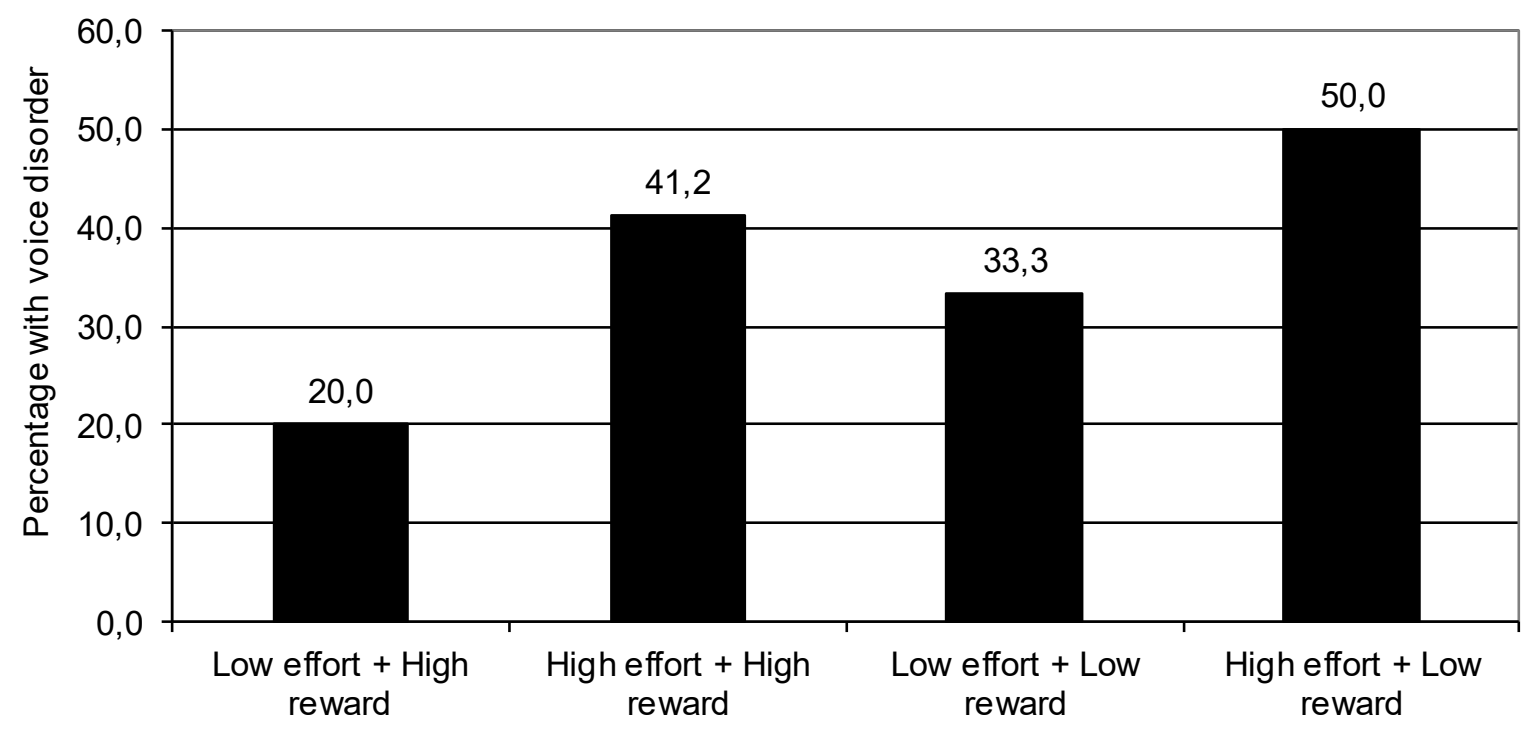

DER

Legend: DER: effort-reward imbalance

Figure 2 - Voice disorder prevalence according to the four categories of the DER

housework and various social roles that have to take can configure a double or triple workday ${ }^{26}$ and all these factors may compromise their professional performance and vocal ${ }^{4,11}$.

Most of the teachers studied reported no work in another location other than the school (100; 90,9\%). This finding is similar to the result of that study 25 found that $75 \%$ of teachers had no other work. Of the $10(9,1 \%)$ working at another location other than the school, $06(60 \%)$ had occupations that required the use of voice (sales, customer service, prayer group leader), a reality that proves that excessive vocal demand can trigger a voice problem.

It is known that the performance of teaching activities is compromised due to a number of environmental factors and work organization. One such factor is the violence in the school physical environment. In this study, the variables "depredations" and "violence against officials" were presented different between CDV and SDV groups and the literature states that the presence of these situations can create stress conditions associated with voice disorder teacher, favoring his illness physical or psychological ${ }^{27}$. A recent study found that factors that represent the direct violence (such as assault, insult, violence to the school gate, violence against other employees and manifestation of racism) are among the most statistically associated factors to the presence of disorder voice of violence against the physical installation or against school supplies ${ }^{28}$.
Scale Effort-Reward Imbalance (DER) is used to measure the level of stress to which the worker is exposed. Conditions of high efforts and low rewards lead to stressful experiences can cause adverse health effects ${ }^{17}$, including voice disorders.

With respect to that scale, the results indicate that in the two older age groups (40-49 and above 50 years old), the surveyed showed a Low DER and the youngest age group (up to 39), a High DER. Our findings are consistent with study ${ }^{29}$ that states that the working of nursing with high DER, compared to professionals with Low DER, are younger, higher education and reported greater impact of the work, especially with regard to emotional content. This category "exposed" to the effort-reward imbalance (High DER) is the category with risk of psychosocial stress. High DER provides higher levels of perceived anxiety, depression and psychological stress by increasing the effects of exhaustion ${ }^{30}$. These authors also showed that the perception of reward component increases significantly with age.

In relation to ICT is contacted that $99,1 \%$ of the teachers had ICT low/ moderate differing from the study of academics who reported $87 \%$ good/great $\mathrm{ICT}^{15}$. We know that the ability to work is considered as a result a dynamic process of individual resources in relation to their work and suffering changes due to various factors, including health status, sociodemographic characteristics, lifestyle, aging and work-related factors ${ }^{14}$. A possible inference of this research finding may be the precarious conditions 
of the school environment, the organization of the labor process and labor relations, precarious this out as source of negative consequences for the health, well-being, quality of life and Teachers productivity for which stress is considered a major triggering agents such consequences.

A higher prevalence of Down ICT among the ten teachers who worked at another location other than the school was observed. Being the "capacity for work" associated with worker's qualifications (based on their physical, mental and social capacity to cope with the demands of work), the teacher expects, in your profession, not only respect and professional recognition, but also good wages, greater autonomy and good physical condition to your desktop. These attributes, however, are not in current teaching work $^{31}$, and may therefore affect the workability. This data can cause teachers to seek other work activity to supplement their income and that brings you professional development. It is noteworthy that the non-recognition of these values, combined with the vocal teacher illness, contributes to the increase in loss of ability to work and the consequent removal of teaching.

\section{CONCLUSION}

From the study it can be concluded that teachers who have over 11 years of teaching, teach in two or more schools and work in schools that always have depredations and violence against employees are more likely to have voice disorder.

The loss of capacity for work and the voice disorder presence are not associated with the high percentage of teachers found in the lower category and moderate ICT. However, it is observed that the percentage of teachers with low ICT was higher in those who worked at another location other than the school. It was observed that the psychosocial work stress was not significant with the presence of voice disorder, but was associated with the age group where there is high DER in the younger teachers.

\begin{abstract}
Purpose: to verify the association between the voice disorder and sociodemographic and organizational data (situations of violence) of teaching, between loss of workability and psychosocial stress at work. Methods: participants were asked to answer the protocols: Condition of Vocal Production of Teacher, Effort-Reward-Imbalance and Work Ability Index. Results: correlation was found between voice disorder and demographics and organizacionals work data in relation the time that teaches $(p=0.028)$, amount of schools that teaches $(p=0,004)$ and to the situations of violence in the issue depredation ( $p=0,037)$; there was no significance between the voice disorder and the scores of EffortReward-Imbalance and Work Ability Index questions $(p>0,05)$. There was an association between sociodemographic data and Effort-Reward-Imbalance and Work Ability Index questions related to age $(p=0,042)$ and variable "Works in elsewhere beyond school" $(p=0,011)$, respectively. Conclusion: it is observed that teachers who have more than 11 years of teaching: teachs in two or more schools, works in schools that happens always depredations and violence against employees, are more likely to have a voice disorder. There was no association between loss of work ability and the presence of the voice disorder. Psychosocial stress was not associated with the presence of voice disorder, but was associated with age, observing high Effort-Reward-Imbalance in younger teachers.
\end{abstract}

KEYWORDS: Quality of Life; Voice; Faculty; Occupational Health 


\section{REFERENCES}

1. Dragone MLS, Ferreira LP, Giannini SPP, SimõesZenari M, Vieira VP, Behlau M. Voz do professor: uma revisão de 15 anos de contribuição fonoaudiológica. Rev Soc Bras Fonoaudiol. 2010;15(2):289-96.

2. Behlau M, Zambon F, Guerrieri AC, Roy N. Panorama epidemiológico sobre a voz do professor no Brasil. Rev Soc Bras Fonoaudiol. 2009;(Supl):1511.

3. Roy N, Merrill RM, Thibeault S, Parsa RA, Gray $\mathrm{SD}$, Smith EM. Prevalence of voice disorders in teachers and the general Population. J Speech Lang Hear Res. 2004;47(2):281-93.

4. Roy N, Merrill RM, Thibeault S, Parsa RA, Gray $\mathrm{SD}$, Smith EM. Voice disorders in teachers and the general population: effects on work performance, attendance and future career choices. J Speech Lang Hear Res. 2004;47(2):542-51.

5. Silverio KCA, Gonçalves CGO, Penteado RZ, Vieira TPG, Libardi A, Rossi D. Ação em saúde vocal: proposta de melhoria do perfil vocal de professores. Pró-Fono R Atual Cient. 2008;20(3):177-82.

6. Souza CL, Carvalho FM, Araújo TM, Reis EJFB, Lima VMC, Porto LA. Fatores associados a patologias de pregas vocais em professores. Rev Saude Publica. 2011;45(5):914-21.

7. Araújo CA. Cuidados com a voz. AMB - Rev Assoc Med Bras. 2004;48:24.

8. Vilkman E. Occupational safety and health aspects of voice and speech professions. Folia Phoniatr Logop. 2004;56(4):220-53.

9. Schwartz SR, Cohen SM, Dailey SH, Rosenfeld RM, Deutsch ES, Gillespie MB et al. Clinical practice guideline: hoarseness (dysphonia). Arch Otolaryngol. - Head \& Neck Surg. 2009; 141(3 Suppl 2):1-31.

10. Sociedade Brasileira de Otorrinolaringologia, Academia Brasileira de Laringologia e Voz, Associação Nacional de Medicina do Trabalho. Consenso Nacional sobre Voz Profissional. 3. Voz e trabalho: uma questão de saúde e direito do trabalhador. Rev Bras Otorrinolaringol. 2004;70(6):68.

11. Soderini Ferracciu CC, Soalheiro MS. O Distúrbio de Voz Relacionado ao Trabalho do professor e a legislação atual. Rev CEFAC. 2013;26(3):628-33.

12. Behlau M, Oliveira G, Santos LMA, Ricarte A. Validação no Brasil de protocolos de auto-avaliação do impacto de uma disfonia. Pró-Fono $\mathrm{R}$ Atual Cient. 2009;21(4):326-32.

13. Ilmarinen J. Aging workers. Occup. environ. med. 2001;58(8):546-52.

14. Marquese EC, Moreno CRC. Satisfação no trabalho e capacidade para o trabalho entre docentes universitários. Psicol. Estud. 2009;14(1):75-82.
15. Giannini SPP. Distúrbio de voz relacionado ao trabalho docente: um estudo caso-controle. 2010. [Tese]. São Paulo (SP): Faculdade de Saúde Pública da Universidade de São Paulo, 2010.

16. Giannini SPP, Latorre MRDO, Ferreira LP. Distúrbio de voz relacionado ao trabalho docente: um estudo caso-controle. CoDAS. 2013;25(6):566-76. http://dx.doi.org/10.1590/ S2317- 17822014000100009.

17. Silva LS, Barreto SM. Adaptação transcultural para o português brasileiro da escala effort-reward imbalance: um estudo com trabalhadores de banco. Rev. Panam. Salud Publica. 2010;27(1):32-6.

18. Silva Junior SHA, Vasconcelos AGG, Griep $\mathrm{RH}$, Rotenberg R. Validade e confiabilidade do Índice de Capacidade para o Trabalho (ICT) em trabalhadores de enfermagem. Caderno de Saúde Pública. 2011;6(27):1077-87.

19. Ghirardi ACAM. Distúrbios de voz em professores: identificação, avaliação e triagem. [Tese]. São Paulo (SP): Pontifícia Universidade Católica de São Paulo; 2012

20. Yamasaki R, Leão SH, Madazio G, Padovani $M$, Azevedo R, Behlau M. Correspondência entre escala analógico-visual e a escala numérica na avaliação perceptivo-auditiva de vozes. In: XVI Congresso Brasileiro de Fonoaudiologia; 2008 Set 24-27; Campos de Jordão - SP. .

21. Ferreira LP et al. Condições de produção vocal de professores da prefeitura do município de São Paulo. Disturb Comum. 2003;2(14):275-307.

22. Ferreira LP, Latorre MRDO, Giannini SPP, Ghirardi ACAM, Karmann DF, Silva EE et al. Influence of abusive vocal habits, hydration, mastication and sleep in the occurrence of vocal symptoms in teachers. J Voice. 2010;24(1):86- 92.

23. Ceballos AGC, Carvalho FM, Araújo TM, Reis EJFB. Avaliação perceptivo-auditiva e fatores associados à alteração vocal em professores. Rev Bras Epidemiol. 2011;14(2):285-95.

24. Marçal CCB, Peres M.A. Alteração vocal auto-referida em professores: prevalência e fatores associados. Rev Saude Publica. 2011;45(3):503-11. 25. Araújo TM, Reis EJB, Carvalho FM, Porto LA, Reis IC, Andrade JM. Fatores associados a alterações vocais em professoras. Caderno de Saúde Pública. 2008;24(6):1229-38.

26. Grillo MHMM, Penteado RZ. Impacto da voz na qualidade de vida de professore(a)s do ensino fundamental. Pró-Fono $\mathrm{R}$ Atual Cient. 2005;17(3):321-30.

27. Giannini SPP, Latorre MRDO, Ferreira LP. Distúrbio de voz e estresse no trabalho docente: um estudo caso-controle. Cad saude publica. 2012;28(11):2115-24. 
28. Ferreira LP, Latorre MRDO, Giannini SPP. A violência nas escolas e os distúrbios de voz de professores. Distúrb Comum. 2011;23(2):165-72.

29. Comaru CM. Estresse psicossocial e vínculo profissional em trabalhadoras da enfermagem: uma análise da flexibilização do trabalho a partir da escala desequilíbrio esforço-recompensa [Dissertação]. Rio de Janeiro (RJ): Escola Nacional de Saúde Pública - Fundação Oswaldo Cruz; 2011.
30. Zurlo MC, Pes D, Siegrist J. Validity and reliability of the effort-reward imbalance questionnaire in a sample of 673 Italian teachers. Int arch occup environ health. 2010;83(6):665-74.

31. Martinez MC. Estudo de fatores associados à capacidade para o trabalho em trabalhadores do Setor Elétrico [Tese]. São Paulo (SP): Universidade de São Paulo, Faculdade de Saúde Pública; 2006.

Received on: October 22, 2014

Accepted on: May 25, 2015

Mailing address

Cristiane Cunha Soderini Ferracciu

Rua Jorge de Lima, 113, Trapiche

Maceió - AL - Brasil

CEP: $57010-300$

E-mail: crissoderini@uol.com.br 